\title{
Comparative susceptibility of turbot, halibut, and cod yolk-sac larvae to challenge with Vibrio spp.
}

\author{
Nina Sandlund ${ }^{1, *}$, Odd M. Rødseth ${ }^{1,4}$, Dag H. Knappskog ${ }^{2}$, Ingrid Uglenes Fiksdal ${ }^{1}$, \\ Øivind Bergh ${ }^{1,3}$
}

\author{
${ }^{1}$ Institute of Marine Research, PO Box 1870 Nordnes, 5817 Bergen, Norway \\ ${ }^{2}$ Intervet Schering-Plough Norbio, Thormøhlensgt. 55, 5008 Bergen, Norway \\ ${ }^{3}$ Department of Biology, University of Bergen, PO Box 7803, 5020 Bergen, Norway
}

${ }^{4}$ Present address: Aqua Gen AS, Havnegata 9, 7010 Trondheim, Norway

\begin{abstract}
In intensive aquaculture systems, high mortalities are frequently observed during the early life stages of marine fish. The aim of this study was to investigate differences in the susceptibility of turbot Scophthalmus maximus, halibut Hippoglossus hippoglossus and cod Gadus morhua to various strains of Vibrio anguillarum (serotypes O1, O2 $\alpha$ and O2 $\beta$ ), V. salmonicida and V. splendidus. The bath challenge experiments were performed using a multidish system, with 1 egg well ${ }^{-1}$. Unchallenged eggs and larvae were used as controls. Larvae in challenged groups that suffered high mortality rates were examined by immunohistochemistry. The overall results with respect to mortality showed that the O2 $\alpha$ serotype was pathogenic to all 3 species, while the O1 serotype was pathogenic to halibut and cod. The immunohistochemical examinations revealed differences in histopathology. The $\mathrm{O} 1$ serotype produced more severe and highly developed infections than the $\mathrm{O} 2 \alpha$ serotype. In larvae exposed to the O1 serotype, necrosis and bacterial cells were seen in the dermis, gastrointestinal tract, brain and eye area, while in larvae exposed to the $\mathrm{O} 2 \alpha$ serotype, bacteria were usually limited to the gastrointestinal tract. These results suggest either that there are undetermined species differences in host immunity or that these pathogens are host-specific even in the early life stages of fish. The O2 $\beta$ strain did not cause an increased mortality to halibut and turbot.
\end{abstract}

KEY WORDS: Yolk-sac larvae • Bath challenge experiment · Immunohistochemistry · Vibrio anguillarum $\cdot$ Vibriosis

\section{INTRODUCTION}

Turbot Scophthalmus maximus, halibut Hippoglossus hippoglossus and cod Gadus morhua are increasingly becoming important species in European aquaculture. However, the production of these species has been limited by unstable production of juveniles due to high mortalities during the larval stages (reviewed by Bricknell \& Dalmo 2005, Samuelsen et al. 2006). Vibriosis has been, and still is, one of the major disease problems of the aquaculture industry. Vibrio anguillarum, $V$. salmonicida, $V$. ordalii and $V$. vulnificus are among the pathogens that lead to the greatest losses in aquaculture all over the world (reviewed by
Toranzo et al. 2005). Good vaccines developed in the late 1980s and early 1990s have reduced the problem in salmonid farming, but vaccines developed for cod still do not provide sufficient protection (reviewed by Sommerset et al. 2005, Bricknell et al. 2006, Samuelsen et al. 2006); thus, vibriosis is still a cause of serious financial losses.

Vibrio salmonicida is the causative agent of 'coldwater vibriosis', which is a disease that commonly occurs during the winter or at temperatures below $15^{\circ} \mathrm{C}$ (Egidius et al. 1986). It is known to be a problem in the farming of salmonid fish, especially the salmon Salmo salar, but little information is available concerning $V$. salmonicida in marine fish species (reviewed by 
Bricknell et al. 2006). V. splendidus has been described as being pathogenic to fish (Thomson et al. 2005, Bergh \& Samuelsen 2007) and bivalves (Gómez-León et al. 2005, Sandlund et al. 2006).

The greatest losses to vibriosis in the aquaculture industry are caused by Vibrio anguillarum, which is a species that has 23 known O serotypes (Pedersen et al. 1999). Individual serotypes are often associated with certain species of fish and not all are believed to be pathogenic. Serotypes associated with disease in farmed fish are O1, O2 and O3 (reviewed by Toranzo et al. 2005). The O2 serotype has been divided into 2 subserotypes (O2 $\alpha$ and $\mathrm{O} 2 \beta)$. While $\mathrm{O} 2 \alpha$ has been isolated from both salmonid and marine fish, O2 $\beta$ is usually isolated from cod and other nonsalmonids (Mikkelsen et al. 2007). In turbot farming, O1 is the dominant serotype (Larsen et al. 1994), while both O1 and O2 cause disease in halibut (Bergh et al. 1997, Bricknell et al. 2000, Hoare et al. 2002). The O3 serotype is rare in comparison with the other 2 and is usually isolated from eels (reviewed by Toranzo et al. 2005).

Despite all the published work on the bacteria listed above, little is known about their capacity to infect fish during their early life stages. Various aspects of differences in host susceptibility to pathogenic agents are also of interest. As new species emerge in the aquaculture industry, it is likely that pathogens will be transferred between species. Although species may not develop the disease, they may act as reservoirs of the pathogen. The objective of this work was to perform a challenge study of turbot, halibut and cod larvae, comparing their susceptibility to different serotypes of $V$. anguillarum, an atypical strain of $V$. salmonicida and a V. splendidus strain.

\section{MATERIALS AND METHODS}

Broodstock, eggs and larvae. Eggs of turbot, halibut, and cod were obtained from broodstock at the Institute of Marine Research, Austevoll Research Station (Storebø, Norway), and incubated as described by Bergh et al. (1997) and Bergh (2000).

Bacterial strains. The bacterial strains and serotypes used are shown in Table 1. Strain HI-610 has previously been used in a range of challenge experiments with cod and halibut (Samuelsen \& Bergh 2004, Skjermo \& Bergh 2004, Vik-Mo et al. 2005, Seljestokken et al. 2006, Engelsen et al. 2008, Sandlund \& Bergh 2008). Strain HI-618 has previously been described by Wiik et al. (1989) (annotated as HI-4791). Strain H-644 was isolated by O. M. Rødseth and K. Andersen (unpubl. data). V. salmonicida strain HI651 (Wiik et al. 1995) was from the Institute of Marine
Table 1. Bacterial strains used in the study

\begin{tabular}{|ll|}
\hline Designation & Bacterial strain/serotype \\
\hline HI-610 & Vibrio anguillarum strain 610 serotype O2 $\alpha$ \\
HI-618 & Vibrio anguillarum strain 618 serotype O2 $\beta$ \\
HI-644 & Vibrio anguillarum strain 644 serotype O1 \\
HI-651 & Vibrio salmonicida strain 651 \\
HI-1576 & Vibrio splendidus strain 1576 \\
\hline
\end{tabular}

Research and V. splendidus strain HI-1576 was originally provided by the National Veterinary Institute, Norway. Strains HI-610 and HI-618 were originally isolated from diseased cod, HI-644 from diseased turbot, and HI-651 and HI-1576 from diseased halibut fry. Following primary isolation and characterisation, all bacterial strains had been stored in the culture collection of the Institute of Marine Research at $-80^{\circ} \mathrm{C}$ in a $20 \%$ glycerol/marine broth (MB, Difco 2216, Difco) stock. They were incubated at $15^{\circ} \mathrm{C}$ and grown on Petri dishes with Difco 2216 marine agar (MA) for $48 \mathrm{~h}$. Colonies of the bacteria were transferred to Erlenmeyer flasks with MB (Difco 2216) and shaken at $80 \mathrm{rpm}$ in a shaking incubator (INFORS AG CH-4103) for $48 \mathrm{~h}$ at $10^{\circ} \mathrm{C}$. It should be noted that bacterial suspensions used for challenging turbot larvae were grown at $15^{\circ} \mathrm{C}$. The bacterial cultures were harvested by centrifugation (Heraeus Sepathec Megafuge 1.0 R) at $2772 \times g$ for $10 \mathrm{~min}$ at $4^{\circ} \mathrm{C}$, washed twice with phosphate-buffered saline (PBS) and suspended in PBS.

All 3 species of fish were challenged with all 5 bacterial strains. Two different challenge doses were used, equivalent to a bath challenge concentration in wells of approximately $10^{6}$ (high) and $10^{4} \mathrm{CFU} \mathrm{ml}^{-1}$ (low). Unchallenged larvae were used as controls. Larval mortality was recorded daily. The challenge protocols were modified from Bergh et al. (1992, 1997).

The eggs are fragile and some were damaged during handling; thus, the challenge groups contained slightly different numbers of larvae.

Challenge experiments. The temperatures used during the experiments were chosen so as to provide nearoptimum conditions for culturing each fish species.

The turbot eggs and larvae were incubated as described by Bergh et al. (1997), in 24-well dishes at $15^{\circ} \mathrm{C}$ in an airconditioned room. The various challenge groups contained either 72 (control, high-challenge dose of HI-618 and low-challenge dose of HI-610), 71 (high-challenge doses of HI-610 and HI-1576 and lowchallenge doses of HI-618 and HI-1576), 70 (high- and low-challenge dose of HI-644) or 69 (high- and lowchallenge dose of HI-651) larvae, as larvae damaged through treatment were killed and discarded. The eggs were challenged $1 \mathrm{~d}$ before hatching. The exper- 
iments lasted for $5 \mathrm{~d}$ post-hatch (dph) until the end of the yolk-sac stage.

The challenge experiments with halibut larvae were performed in darkness in an airconditioned room at $6^{\circ} \mathrm{C}$ as described by Bergh et al. $(1992,1997)$. The eggs were challenged $4 \mathrm{~d}$ before hatching. One day after hatching, the wells were washed, the water and eggshell remains were removed, and $10 \mathrm{ml}$ of sterile seawater was added. These challenge groups contained either 60 (control larvae, larvae challenged with HI-610 or HI-576) or 58 (larvae challenged with HI618, HI-644 or HI-651) larvae. The halibut larvae were only exposed to the highest challenge dose. Halibut larvae have a long yolk-sac stage and this experiment lasted for $23 \mathrm{dph}$.

Cod eggs and larvae were incubated and challenged as described by Bergh (2000). In this experiment, 24well dishes were used, with $2 \mathrm{ml}$ sterile seawater and 1 egg well ${ }^{-1}$. The eggs were incubated at $6^{\circ} \mathrm{C}$. All challenge groups contained 72 larvae except the group challeged with a low dose of HI-610 that contained 69 larvae, and were challenged $7 \mathrm{~d}$ before hatching. The experiments lasted for $10 \mathrm{dph}$ until the end of the yolksac stage. Two separate larval batches were challenged in order to verify the reproducibility of the experimental protocol.

Antisera. Antisera were made for Vibrio anguillarum strains HI-610 and HI-644 according to the method described by Oeding (1957) and the standard protocol of the University of Bergen, Laboratory Animal Facility (the Vivarium), in which formaldehyde-killed, washed bacteria were administrated by intravenous injection to rabbits. The polyclonal antisera were absorbed as described by Knappskog et al. (1993), in order to minimize the possibility of cross-reaction. The anti$V$. anguillarum serum was absorbed against the other serotypes used in this experiment; i.e. the $\mathrm{O} 2 \alpha$ serotype serum was absorbed against serotype O2 $\beta$ and serotype O1 strain HI-644. Each of the absorbed antisera was tested for cross-reaction with other $V$. anguillarum strains and tissue samples prior to immunohistochemistry. No cross-reaction or background staining was observed. The dilution used on tissue samples was determined after testing a range of antiserum dilutions on tissue samples.

Immunohistochemistry. In order to provide material for immunohistological examinations, additional multiwell dishes were set up within the different treatments. Two or 3 larvae were taken from each treatment group daily during periods of mortality throughout the experiment. Larval samples were fixed in $4 \%$ phosphatebuffered formaldehyde, dehydrated in ethanol, cleared in xylene and embedded in paraffin. They were sectioned at $3 \mu \mathrm{m}$ (Leica Jung Biocut 2035), incubated at $58^{\circ} \mathrm{C}$ for $30 \mathrm{~min}$, dewaxed in xylene, rehy- drated in a series of ethanol baths and washed in running tapwater. The absorbed polyclonal antisera, anti- $V$. anguillarum 610 and 644 were diluted in Tris buffer with $2.5 \%$ BSA. In order to prevent nonspecific antibody binding, sections were blocked by using $5 \%$ BSA in Tris for 20 min. Biotinylated swine anti-rabbit immunoglobulin was used as a secondary antibody (Dako A/S), and Avidin-biotin-peroxidase-complex (ABComplex/HRP) reaction kit (Dako A/S) and AEC+ Substrate Chromagen (Dako) were used to stain all samples. Positive bacterial staining was indicated by red coloration. Shandon's haematoxylin was used for counterstaining, coloring the tissue blue. Unchallenged larvae were used as negative controls. Bacterial smears on microscope slides were used as positive controls. This control procedure has previously been used with different Vibrio spp. at our laboratory (Sandlund et al. 2006). The antiserum against strain HI-610 has previously been tested in cod larvae (Engelsen et al. 2008). All incubations were performed at room temperature $\left(20^{\circ} \mathrm{C}\right)$ in a humidity chamber in a fume hood.

Statistical analyses. Since the survival and mortality data were not normally distributed, nonparametric tests were used. A $2 \times 2$ contingency table $(p<0.01)$ with Bonferroni correction for multiple independent tests (implemented using Statistica v 7.0, StatSoft) was used to test for mortality differences among the treatment and control groups. Since multiple independent tests were used to test for differences in mortality rate among all the challenged larval groups and the 3 larval control groups, a Bonferroni correction was applied in order to minimize the possibility of making a type II error (Rice 1989). We thus tested for 5 bacterial strains, and the p-value was corrected by a factor of 5 ( $p=$ $0.05 / 5=0.01$ ) (see Rice 1989). Yates' correction was used since there was only $1 \mathrm{df}$.

\section{RESULTS}

\section{Challenge experiments}

All undamaged eggs hatched normally. The cumulative mortality and statistical analysis showed that turbot larvae suffered the highest mortality when challenged with Vibrio anguillarum serotype O2 $\alpha$ (Fig. 1, HI-610). Mortality was found to be significantly different from that in the control group at $2 \mathrm{dph}$ in both highand low-challenge dose groups $(\mathrm{p}<0.01$ Bonferroni correction, Fig. 1). Towards the end of the experiment (4 and/or $5 \mathrm{dph}$ ), the larval groups challenged with low doses of $V$. splendidus (HI-1576) and V. anguillarum serotype O1 (HI-644) respectively, suffered mortality that was significantly different from that of the control group (Fig. 1). 
Halibut larvae were most susceptible to Vibrio anguillarum serotype $\mathrm{O} 2 \alpha$ (HI-610) and serotype O1 (HI-614) (Fig. 2). Statistical analysis showed that mortality in these challenge groups was significantly dif-

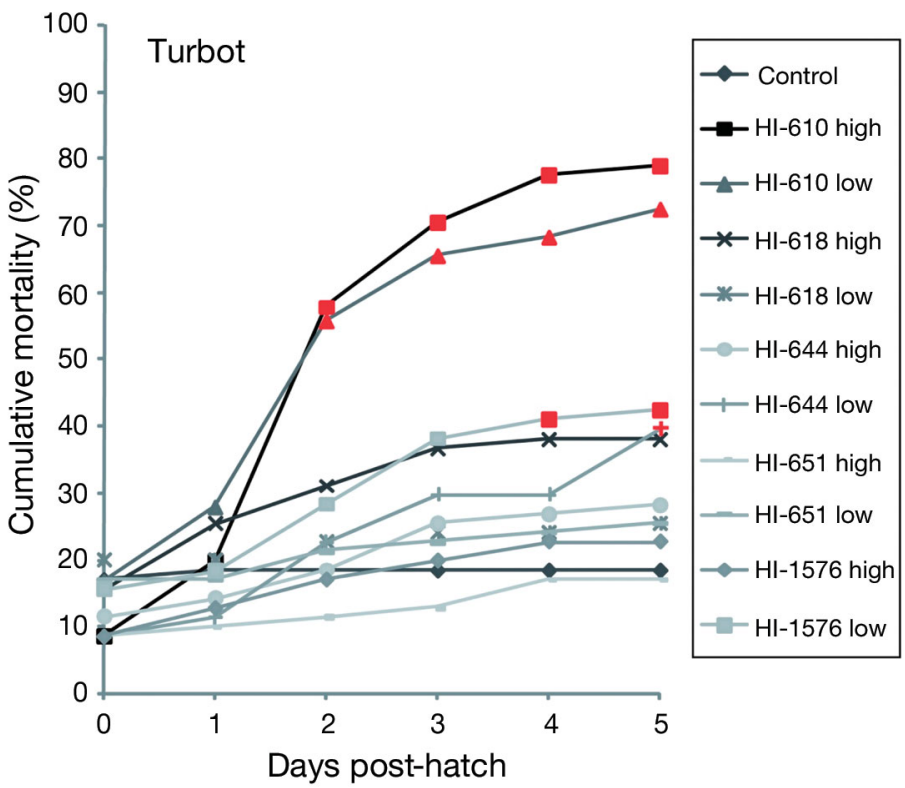

Fig. 1. Scophthalmus maximus. Cumulative percentage mortality of turbot larvae challenged with the bacterial strains HI-610, HI-618, HI-644, HI-651, and HI-1576 (see Table 1 for

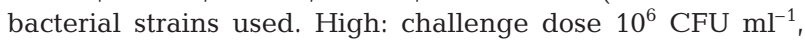
low: challenge dose $10^{4} \mathrm{CFU} \mathrm{ml}^{-1}$, control: unchallenged larvae. Day 0: day of hatching. Red symbols: mortality rates significantly different from the control $(\mathrm{p}<0.01$ Bonferroni correction)

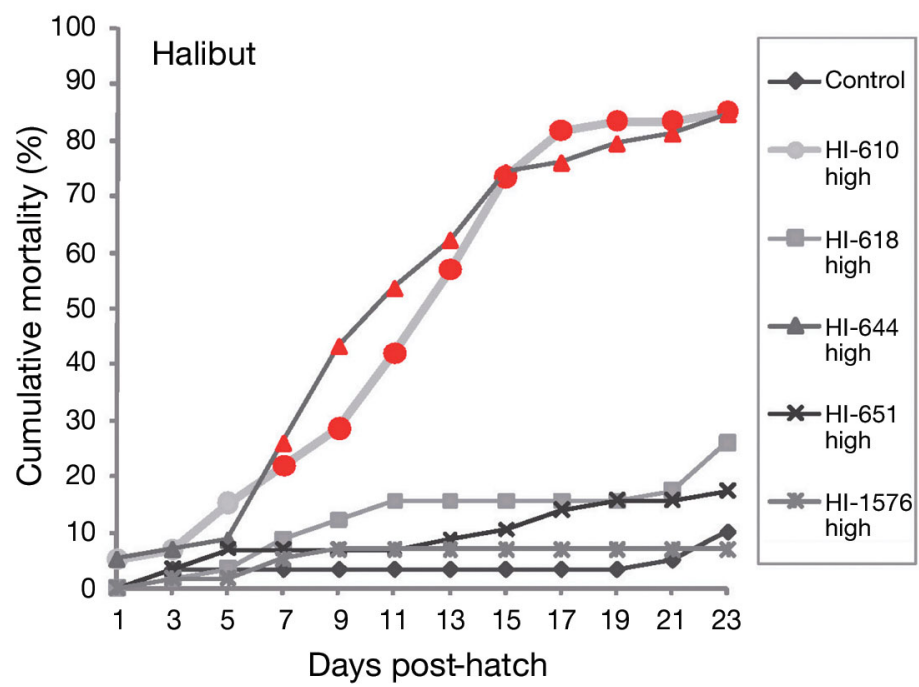

Fig. 2. Hippoglossus hippoglossus. Cumulative percentage mortality of halibut larvae challenged with the bacterial strains HI-610, HI-618, HI-644, HI-651, and HI-1576 (see Table 1 for bacterial strains used). High: challenge dose $10^{6}$ CFU ml $\mathrm{m}^{-1}$, control: unchallenged larvae. Red symbols: mortality rates significantly different from the control $(\mathrm{p}<0.01$ Bonferroni correction) ferent from that of the control group from $7 \mathrm{dph}$ onward ( $p<0.01$ Bonferroni correction, Fig. 2).

The cumulative mortalities in the 2 separate groups of cod larvae were similar (data not shown), so the cumulative mortality and statistical analysis are shown for only one of the groups (Fig. 3). Cod larvae showed equal susceptibility to the high-challenge dose of Vibrio anguillarum serotype $\mathrm{O} 1$ (HI-644) and $\mathrm{O} 2 \alpha$ (HI-610). Statistical analysis showed that the mortalities of these challenge groups were significantly different from that of the control group starting at 3 and $4 \mathrm{dph}$, respectively ( $\mathrm{p}<0.01$ Bonferroni correction). In the low-challenge dose groups, the only observed significant difference in mortality, which was between the control and the group challenged with $V$. anguillarum serotype $\mathrm{O} 2 \alpha$ started from $7 \mathrm{dph}$ onward. Although the cumulative mortality reached $35 \%$ in the high-challenge dose group of $V$. anguillarum serotype $\mathrm{O} 2 \beta$ (HI-618), this was significantly different from that in the control only at 7 and $8 \mathrm{dph}(\mathrm{p}<0.01$ Bonferroni correction).

\section{Immunohistochemistry}

Immunohistochemical examinations were used for verification instead of re-isolation of bacteria, and were therefore performed on the larval groups that suffered the highest mortality rates compared to the control group. No control larvae were positively immunostained by either of the antisera (Fig. 4a).

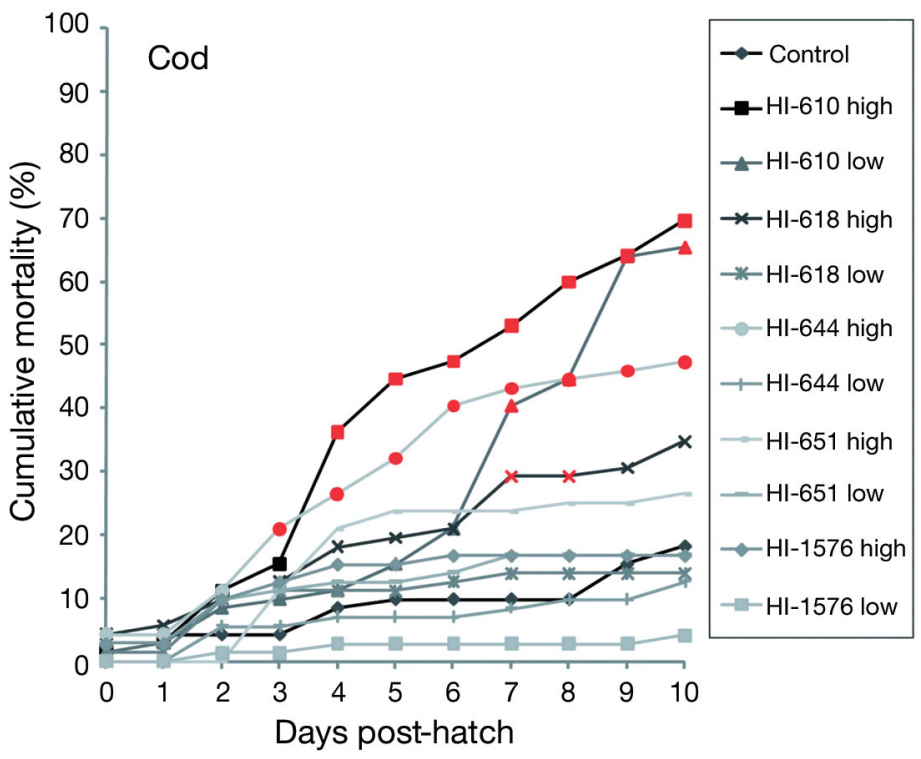

Fig. 3. Gadus morhua. Cumulative percentage mortality of cod larvae challenged with the same bacterial strains and doses as in Fig. 1. Day 0: day of hatching. Red symbols: mortality rates significantly different from the control group ( $p<0.01$ Bonferroni correction) 
The immunohistochemical findings in turbot larvae challenged with Vibrio anguillarum serotype $\mathrm{O} 2 \alpha$ (HI-610) demonstrated the presence of bacteria in the gastrointestinal tract, abdominal cavity, gallbladder (Fig. 4b) and kidney.
Differences in histopathology were observed in halibut larvae challenged with Vibrio anguillarum serotype O1 (HI-644) and O2 $\alpha$ (HI-610) (Fig. 4c,d). Tissue damage was mostly found in larvae challenged with the O1 serotype. Large quantities of bacteria sur-
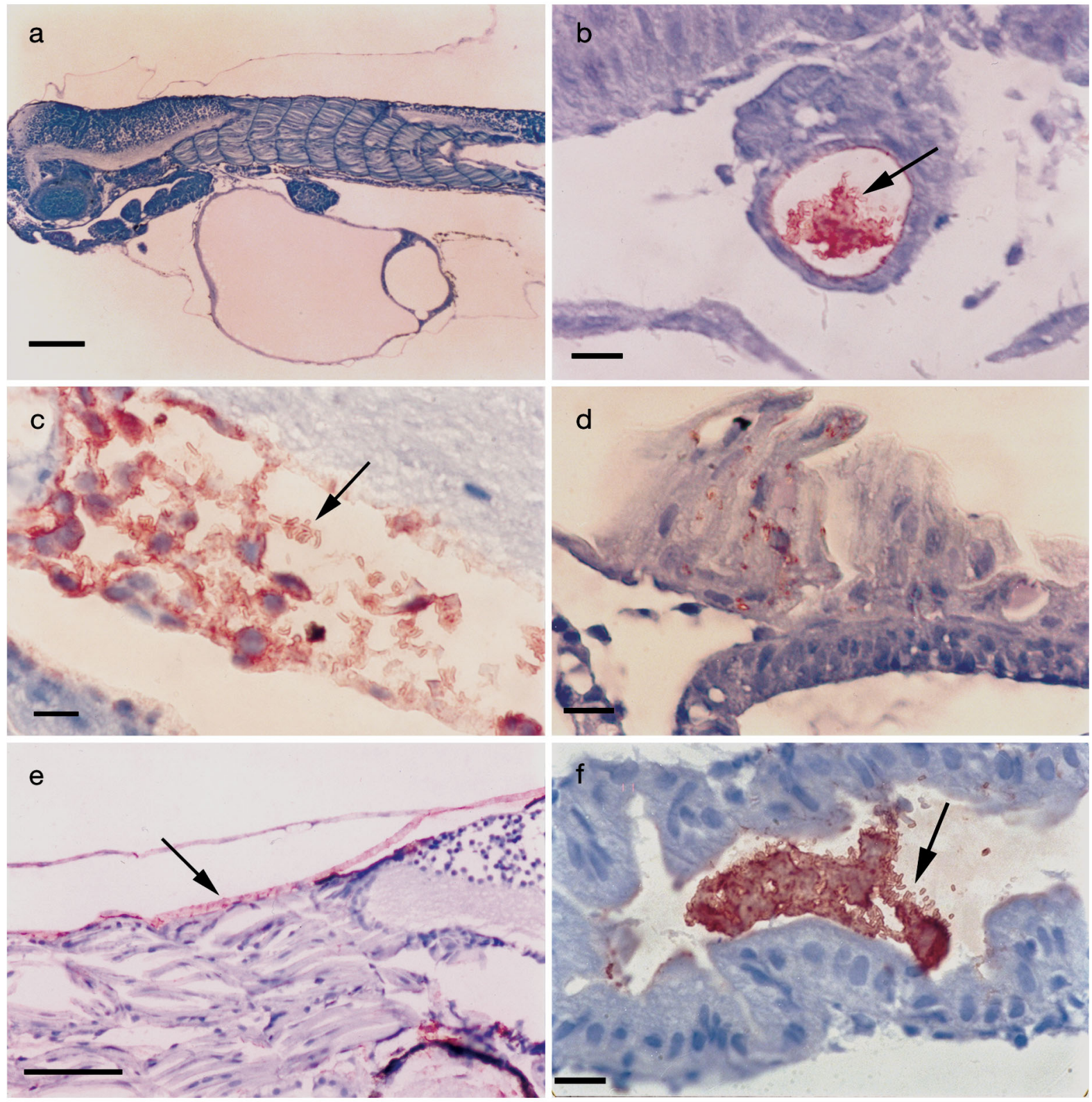

Fig. 4. Scophthalmus maximus, Hippoglossus hippoglossus, Gadus morhua. Immunohistochemical staining of paraffin sections from larvae using the Avidin-biotin method, rabbit anti-Vibrio anguillarum HI-610 and $V$. anguillarum HI-644 sera, and Shandon haematoxylin counterstain. Positive immunohistochemistry is visualized by red coloring of the bacteria. Counterstaining gives tissue different tones of blue. (a) Turbot $S$. maximus control larva, showing no positive immunostaining. Magnification: 100 $\times_{i}$ scale bar: $100 \mu \mathrm{m}$. (b) Turbot challenged with $V$. anguillarum HI-610, showing positive immunostaining of bacteria in gallbladder (arrow). Magnification: 1000×; scale bar: $10 \mu \mathrm{m}$. (c) Halibut $H$. hippoglossus challenged with $V$. anguillarum HI-644, showing brain tissue with necrosis and free bacteria (arrow). Magnification: 1000x; scale bar: $10 \mu m$. (d) Halibut challenged with $V$. anguillarum HI-610, showing positive staining of bacteria associated with sensory cells on the dorsal side of the head. Magnification: $1000 x_{i}$ scale bar: $10 \mu \mathrm{m}$. (e) Cod G. morhua challenged with $V$. anguillarum HI-644, showing positive immunostaining in dermis and muscle tissues (arrow). Magnification: 400x; scale bar: $50 \mu \mathrm{m}$. (f) Cod challenged with V. anguillarum HI-610, showing positive immunostaining of bacteria in intestine (arrow). Magnification: $1000 x_{i}$ scale bar: $10 \mu \mathrm{m}$ 
rounding necrotic cells were found in the dermis and in brain (Fig. 4c), and liquefactive necrosis was seen in striated muscle cells of muscle tissue (data not shown). Necrotic tissue was infiltrated with bacteria, and unattached bacteria were also observed in the yolk-sac area, gastrointestinal tract and the area around the eyes (data not shown). In halibut larvae challenged with the O2 $\alpha$ serotype (HI-610), histopathology was limited to a few necrotic cells in the dermis and positive staining of bacteria in early developed sensory cells on the dorsal side of the head (Fig. 4d). Bacteria were also observed in the gastrointestinal tract (data not shown).

In cod larvae challenged with the O1 serotype (HI-644), bacteria were observed in the dermis and the head region (Fig. 4e). In larvae challenged with the O2 $\alpha$ serotype (HI-610), bacteria were only observed in the gastrointestinal tract (Fig. 4f). All the cod larvae examined displayed few signs of pathology.

\section{DISCUSSION}

The results revealed differences in susceptibility among turbot, halibut and cod larvae to various serotypes of Vibrio anguillarum. The high-challenge dose of $V$. anguillarum serotypes $\mathrm{O} 2 \alpha$ and $\mathrm{O} 1$ had a significantly negative effect on halibut and cod larvae. Turbot larvae were mostly affected by the $\mathrm{O} 2 \alpha$ serotype. The difference in mortality observed at the end of the experiment for the turbot larval group challenged with the low-challenge dose of the O1 serotype strain, could be an artifact as this is at the end of the non-feeding yolk-sac period. If this bacterial strain had been pathogenic to these larvae, the same mortality should have been observed in the high-challenge dose group as well. This suggestion is supported by the immunohistochemical findings that showed no pathology in examined larvae. The fact that the O1 serotype seemed to affect cod and halibut the most would suggest that there are differences in the immune system among the 3 species and/or that the bacterium has a preference for one specific host. The nonspecific immune system has been studied in cod (Lange et al. 2004, reviewed by Falk-Petersen 2005) and halibut larvae to a certain extent (Lange et al. 2006, reviewed by Falk-Petersen 2005). In cod larvae, the complement component $\mathrm{C} 3$ was detected at $1 \mathrm{dph}$ and was found in most organs at 15 dph (Lange et al. 2004). In halibut, the C3 factor was found at $30 \mathrm{dph}$ (Lange et al. 2006); however, this was the earliest sampling in that particular study. Patel et al. (2009) found that the lymphoid organs were not morphologically well developed until the late metamorphic stage and that immunoglobulin M (IgM) proteins were detected from Day 94 onward.
Similarly in turbot, the spleen and thymus appear at the end of the yolk-sac stage (reviewed by Falk-Petersen 2005), indicating that the specific immune response can be expected after this stage. A recent study by Corripio-Miyar et al. (2007) of IgM development in the haddock Melanogrammus aeglefinus, suggests that the immune system starts to develop at $\sim 25$ to $29 \mathrm{dph}$. In view of the present knowledge on the development of the specific immune system in cod and halibut (Schrøder et al. 1998, Lange et al. 2006, Patel et al. 2009), it should be emphasized that the present experiment was conducted at developmental stages at which the specific immune system was immature or even undeveloped. Preference for a particular host species has been found among $V$. anguillarum strains that were tested on different species of fish mucus (Larsen et al. 2001). The same study showed an overall preference for rainbow trout mucus over mucus from cod, common bream Abramis brama and flounder Platichtys flesus. Differences in host susceptibility to Mycobacterium marinum have also been found (Wolf \& Smith 1999). The study showed great differences in the inflammatory response between striped bass, Morone saxatilis, and the tilapia hybrid Oreochromis niloticus $\times O$. mossambicus $\times O$. aureus. The striped bass that experienced the highest mortality also displayed the most severe clinical signs (granulomas with necrosis and inflammation). Differences in virulence have also been shown in experiments involving various species of bivalves that were exposed to different Vibrio strains (Nicolas et al. 1992, 1996, Luna-González et al. 2002).

As previously described, Vibrio anguillarum serotype $\mathrm{O} 2 \beta$ is the strain that is most frequently associated with disease in cod and nonsalmonid fish (Mikkelsen et al. 2007). The O2ß isolate used in this study did not have negative effects on turbot and halibut larvae but in the cod larval experiments the mortality results were not as straightforward. In the cod experiments, significant differences in mortality were observed on Days 7 and 8 post-hatch but not at the end of the experiment, indicating that this isolate could not be highly pathogenic. This is also supported by the immunohistochemical examinations. A difference in virulence between the $\mathrm{O} 2 \alpha$ and the O1 serotype was also verified in terms of challenge dose. The low-challenge dose (tested with cod and turbot only) of the O2 $\alpha$ serotype was pathogenic to turbot and cod larvae, while the low-challenge dose of the O1 serotype only seemed to have a minor negative effect, if any, on turbot larvae. Differences in the virulence of $V$. anguillarum strains have previously been reported (Larsen et al. 1988, reviewed by Toranzo \& Barja 1990, Lemos et al. 1991, Pedersen et al. 1997), but the mechanisms involved are often debated. The presence of iron-uptake mechanisms is regarded as essential for virulence (reviewed by Johansson \& Cos- 
sart 2003), although nonpathogenic $V$. anguillarum strains are known to possess similar systems (Lemos et al. 1991). Pedersen et al. (1997) compared the virulence of $V$. anguillarum serotype $\mathrm{O} 1$ isolates to the presence of virulence plasmids, outer membrane proteins and siderophore production. They found that all virulent strains carried a specific $67 \mathrm{kbp}$ virulence plasmid and produced the outer membrane protein OM2. However, some strains that were carrying the virulence plasmid and producing both the membrane protein and siderophores proved to be nonvirulent; hence, the authors suggested that other factors might also be involved in virulence. All these studies emphasize the complexity of virulence studies and that it is likely that more than one factor need to be present, or that different strains use different mechanisms of virulence.

The increase in mortality started at different days post-hatch in the 3 species (Figs. 1 to 3 ). In the halibut group, mortality increased at $7 \mathrm{dph}$, while in the turbot and cod groups, it started at $2 \mathrm{dph}$ and 3 to $4 \mathrm{dph}$, respectively. This may be partly related to rearing temperature. Our halibut and cod were reared at $6^{\circ} \mathrm{C}$ (compared to $15^{\circ} \mathrm{C}$ for turbot), which may slow down bacterial growth and delay infection. In addition, it must be emphasized that ontogenetic development occurs far more rapidly in turbot than in halibut, while cod has an intermediate development rate.

The immunohistochemical examinations revealed differences in the infection caused by the Vibrio anguillarum serotypes $\mathrm{O} 1$ and $\mathrm{O} 2 \alpha$. The infection caused by $V$. anguillarum serotype $\mathrm{O} 1$ was more extensive (Fig. 4c,e) than that caused by the $\mathrm{O} 2 \alpha$ serotype (Fig. 4b,d,f ), which usually took the form of bacteria in the gastrointestinal tract. These findings are similar to those observed by Engelsen et al. (2008), who found that cod yolk-sac larvae challenged with the $V$. anguillarum $\mathrm{O} 2 \alpha$ strain experienced high mortality. Engelsen et al.'s histopathological observations were few and suggested excretion of bacterial toxins as a possible cause of death. The histological findings in the present study suggest that different bacterial strains use different host interactions and mechanisms of infection. This was also suggested by Larsen et al. (1988), based on haemagglutination tests and hydrophobic interaction chromatography of various serotype $\mathrm{O} 1$ and $\mathrm{O} 2$ isolates.

The portal of entry and preferred adherence and attachment sites of Vibrio anguillarum are currently debated. The suggestion that $V$. anguillarum may have a stronger tendency to adhere to intestinal than to skin mucosa was a result of studies performed on turbot (Oisson et al. 1996) and rainbow trout Oncorhynchus mykiss mucus (O'Toole et al. 1999). These studies were performed using the $\mathrm{O} 1$ and $\mathrm{O} 2 \alpha$ serotypes, respec- tively. The skin has been suggested to be the major attachment and proliferation site in ayu Plecoglossus altivelis and rainbow trout (Kanno et al. 1989, Spanggaard et al. 2000, respectively). The gills have also been suggested as an infection site in rainbow trout Salmo gairdneri (Baudin Laurencin \& Germon 1987). On the other hand, it has been reported that $V$. anguillarum serotype $\mathrm{O} 2$ does not adhere to mucus in the same way as the O1 serotype but rather to other components of the epithelial surface (Knudsen et al. 1999). These authors suggested that $V$. anguillarum O2 might employ an infection strategy involving adhesion to mucus. The above references all illustrate the complexity of and variables involved in these kinds of studies, the use of different species and bacterial strains, but more importantly, they suggest the possibility that different strains of $V$. anguillarum have different host infection strategies.

The Vibrio splendidus and V. salmonicida strains that we tested did not cause a rise in mortality compared to the control group. Turbot larvae exposed to $V$. splendidus experienced a significantly higher mortality than the controls only at the end of the experiment, probably due to the lack of feeding as the yolksac stage was ending. As reviewed by Thompson et al. (2004), V. splendidus was originally described as a nonpathogenic strain that was isolated from the aquatic environment. However, Reid et al. (2009) recently demonstrated mortality of cod larvae in challenge experiments with $V$. splendidus, following oral administration via live feed. Avirulent strains of $V$. splendidus have previously been reported in challenge experiments performed on halibut larvae (Verner-Jeffreys et al. 2003) and turbot (60 g) (Farto et al. 1999). V. salmonicida is associated with mortality at low temperatures and is regarded as nonpathogenic to salmon at temperatures $>10^{\circ} \mathrm{C}$ (Enger et al. 1991). The temperatures used in the halibut and cod experiments should therefore be optimal for virulence studies that use this bacterium. In the turbot study performed at $15^{\circ} \mathrm{C}$, the temperature may have been too high to cause disease. Following the findings of Reid et al. (2009), it could also be hypothesized that $V$. splendidus is dependent upon oral administration to cause mortality.

In conclusion, the different strains of Vibrio anguillarum caused different mortalities to the 3 different species of fish larvae. Thus, species-specific interactions between bacteria and host may well be present at the yolk-sac stage of fish. We further conclude that immunohistochemistry with absorbed polyclonal antisera is a powerful tool for investigating bacterial infections in fish larvae, including demonstrating the presence of bacteria and pathological alterations in various tissues. 


\section{LITERATURE CITED}

Baudin Laurencin F, Germon E (1987) Experimental infection of rainbow trout, Salmo gairdneri R., by dipping in suspensions of Vibrio anguillarum: ways of bacterial penetration; influence of temperature and salinity. Aquaculture 67:203-205

Bergh Ø (2000) Bacterial pathogens associated with early life stages of marine fish. Proc 8th Int Symp Microb Ecol, Atlantic Canada Society for Microbial Ecology, Halifax, p 221-228

> Bergh Ø, Samuelsen OB (2007) Susceptibility of corkwing wrasse Symphodus melops, goldsinny wrasse Ctenolabrus rupestis, and Atlantic salmon Salmo salar smolt, to experimental challenge with Vibrio tapetis and Vibrio splendidus isolated from corkwing wrasse. Aquacult Int 15: $11-18$

Bergh Ø, Hansen GH, Taxt RE (1992) Experimental infection of eggs and yolk-sac larvae of halibut, Hippoglossus hippoglossus L. J Fish Dis 15:379-391

Bergh Ø, Hjeltnes B, Skiftesvik AB (1997) Experimental infection of turbot Scophthalmus maximus and halibut Hippoglossus hippoglossus yolk sac larvae with Aeromonas salmonicida subsp. salmonicida. Dis Aquat Org 29:13-20

Bricknell I, Dalmo RA (2005) The use of immunostimulants in fish larval aquaculture. Fish Shellfish Immunol 19: 457-472

Bricknell IR, Bowden TJ, Verner-Jeffreys DW, Bruno DW, Shields RJ, Ellis AE (2000) Susceptibility of juvenile and sub-adult Atlantic halibut (Hippoglossus hippoglossus L.) to infection by Vibrio anguillarum and efficacy of protection induced by vaccination. Fish Shellfish Immunol 10: 319-327

Bricknell IR, Bron JE, Bowden TJ (2006) Diseases of gadoid fish in cultivation: a review. ICES J Mar Sci 63:253-266

> Corripio-Miyar Y, Bird S, Treasurer JW, Secombes CJ (2007) RAG-1 and IgM genes, markers for early development of the immune system in the gadoid haddock, Melanogrammus aeglefinus, L. Fish Shellfish Immunol 23:71-85

Egidius E, Wiik R, Andersen K, Hoff KA, Hjeltnes B (1986) Vibrio salmonicida sp. nov. A new fish pathogen. Int J Syst Bacteriol 36:518-520

Engelsen AR, Sandlund N, Fiksdal IU, Bergh Ø (2008) Immunohistochemistry of Atlantic cod larvae Gadus morhua experimentally challenged with Vibrio anguillarum. Dis Aquat Org 80:13-20

Enger Ø, Husevåg B, Goksøyr J (1991) Seasonal variation in presence of Vibrio salmonicida and total bacterial counts in Norwegian fish farm-water. Can J Microbiol 37: 618-623

Falk-Petersen IB (2005) Comparative organ differentiation during early life stages of marine fish. Fish Shellfish Immunol 19:397-412

Farto R, Montes M, Perez MJ, Nieto TP, Larsen JL, Pedersen K (1999) Characterization by numerical taxonomy and ribotyping of Vibrio splendidus biovar 1 and Vibrio scophthalmi strains associated with turbot cultures. J Appl Microbiol 86:796-804

Gómez-León J, Villamil L, Lemos ML, Novoa B, Figueras A (2005) Isolation of Vibrio alginolyticus and Vibrio splendidus from aquacultured carpet shell clam (Ruditapes decussatus) larvae associated with mass mortalities. Appl Environ Microbiol 71:98-104

Hoare R, Hovland H, Langston AL, Imsland A, Stefansson SO, Mulcahy M, Wergeland HI (2002) Susceptibility of three different strains of juvenile Atlantic halibut (Hippoglossus hippoglossus L.) cultured at two different temperatures to
Vibrio anguillarum and temperature effect on antibody response. Fish Shellfish Immunol 13:111-123

Johansson J, Cossart P (2003) RNA-mediated control of virulence gene expression in bacterial pathogens. Trends Microbiol 11:280-285

Kanno T, Nakai T, Muroga K (1989) Mode of transmission of vibriosis among ayu Plecoglossus altivelis. J Aquat Anim Health 1:2-6

Knappskog DH, Rodseth OM, Slinde E, Endresen C (1993) Immunochemical analyses of Vibrio anguillarum strains isolated from cod, Gadus morhua L, suffering from vibriosis. J Fish Dis 16:327-338

Knudsen G, Sørum H, Press CM, Olafsen JA (1999) In situ adherence of Vibrio spp. to cryosections of Atlantic salmon, Salmo salar L., tissue. J Fish Dis 22:409-418

$>$ Lange S, Bambir S, Dodds AW, Magnadóttir B (2004) The ontogeny of complement component $\mathrm{C} 3$ in Atlantic cod (Gadus morhua L.) - an immunohistochemical study. Fish Shellfish Immunol 16:359-367

> Lange S, Bambir SH, Dodds AW, Bowden T, Bricknell I, Espelid S, Magnadóttir B (2006) Complement component C3 transcription in Atlantic halibut (Hippoglossus hippoglossus L.) larvae. Fish Shellfish Immunol 20:285-294

> Larsen JL, Rasmussen HB, Dalsgaard I (1988) Study of Vibrio anguillarum strains from different sources with emphasis on ecological and pathobiological properties. Appl Environ Microbiol 54:2264-2267

Larsen JL, Pedersen K, Dalsgaard I (1994) Vibrio anguillarum serovars associated with vibriosis in fish. J Fish Dis 17: 259-267

> Larsen MH, Larsen JL, Olsen JE (2001) Chemotaxis of Vibrio anguillarum to fish mucus: role of the origin of the fish mucus, the fish species and the serogroup of the pathogen. FEMS Microbiol Ecol 38:77-80

Lemos ML, Mazoy R, Conchas RF, Toranzo AE (1991) Presence of iron uptake mechanisms in environmental nonpathogenic strains of Vibrio anguillarum. Bull Eur Assoc Fish Pathol 11:150-152

> Luna-González A, Maeda-Martínez AN, Sainz JC, AscencioValle F (2002) Comparative susceptibility of veliger larvae of four bivalve mollusks to a Vibrio alginolyticus strain. Dis Aquat Org 49:221-226

Mikkelsen H, Lund V, Martinsen LC, Gravningen K, Schrøder MB (2007) Variability among Vibrio anguillarum O2 isolates from Atlantic cod (Gadus morhua L.): characterisation and vaccination studies. Aquaculture 266:16-25

- Nicolas JL, Ansquer D, Cochard JC (1992) Isolation and characterization of a pathogenic bacterium specific to manila clam Tapes philippinarum larvae. Dis Aquat Org 14:153-159

Nicolas JL, Corre S, Gauthier G, Robert R, Ansquer D (1996) Bacterial problems associated with scallop Pecten maximus larval culture. Dis Aquat Org 27:67-76

O'Toole R, Lundberg S, Fredriksson SA, Jansson A, Nilsson B, Wolf-Watz H (1999) The chemotactic response of Vibrio anguillarum to fish intestinal mucus is mediated by a combination of multiple mucus components. J Bacteriol 181:4308-4317

Oeding P (1957) Agglutinability of pyrogenic Staphylococci at various conditions. Acta Pathol Microbiol Scand 41: 310-324

> Oisson JC, Jöborn A, Westerdahl A, Blomberg L, Kjelleberg S, Conway PL (1996) Is the turbot, Scophthalmus maximus (L), intestine a portal of entry for the fish pathogen Vibrio anguillarum? J Fish Dis 19:225-234

$>$ Patel S, Sørhus E, Fiksdal IU, Espedal PG and others (2009) Ontogeny of lymphoid organs and development of IgM- 
bearing cells in Atlantic halibut (Hippoglossus hippoglossus L.). Fish Shellfish Immunol 26:385-395

Pedersen K, Gram L, Austin DA, Austin B (1997) Pathogenicity of Vibrio anguillarum serogroup O1 strains compared to plasmids, outer membrane protein profiles and

> Pedersen K, Grisez L, van Houdt R, Tiainen T, Ollevier F, Larsen JL (1999) Extended serotyping scheme for Vibrio anguillarum with the definition and characterization of seven provisional O-serogroups. Curr Microbiol 38: 183-189

Reid HI, Treasurer JW, Adam B, Birkbeck TH (2009) Analysis of bacterial populations in the gut of developing cod larvae and identification of Vibrio logei, Vibrio anguillarum and Vibrio splendidus as pathogens of cod larvae. Aquaculture 288:36-43

Rice WR (1989) Analyzing tables of statistical tests. Evolution 43:223-225

Samuelsen OB, Bergh $\varnothing$ (2004) Efficacy of orally administered florfenicol and oxolinic acid for the treatment of vibriosis in cod (Gadus morhua). Aquaculture 235:27-35

Samuelsen OB, Nerland AH, Jørgensen T, Schrøder MB, Svåsand T, Bergh Ø (2006) Viral and bacterial diseases of Atlantic cod Gadus morhua, their prophylaxis and treatment: a review. Dis Aquat Org 71:239-254

Sandlund N, Bergh Ø (2008) Screening and characterisation of potentially pathogenic bacteria associated with Atlantic cod Gadus morhua larvae: bath challenge trials using a multidish system. Dis Aquat Org 81:203-217

Sandlund N, Torkildsen L, Magnesen T, Mortensen S, Bergh $\varnothing$ (2006) Immunohistochemistry of great scallop Pecten maximus larvae experimentally challenged with pathogenic bacteria. Dis Aquat Org 69:163-173

Schrøder MB, Villena AJ, Jørgensen TO (1998) Ontogeny of lymphoid organs and immunoglobulin producing cells in Atlantic cod (Gadus morhua L.). Dev Comp Immunol 22:507-517

Seljestokken B, Bergh Ø, Melingen GO, Rudra H, Olsen RH, Samuelsen OB (2006) Treating experimentally induced vibriosis (Listonella anguillarum) in cod, Gadus morhua L., with florfenicol. J Fish Dis 29:737-742

Skjermo J, Bergh Ø (2004) High-M alginate immunostimulation of Atlantic halibut (Hippoglossus hippoglossus L.) siderophore production. J Appl Microbiol 82:365-371

larvae using Artemia for delivery, increases resistance against vibriosis. Aquaculture 238:107-113

Sommerset I, Krossøy B, Biering E, Frost P (2005) Vaccines for fish in aquaculture. Expert Rev Vaccines 4:89-101

Spanggaard B, Huber I, Nielsen J, Nielsen T, Gram L (2000) Proliferation and location of Vibrio anguillarum during infection of rainbow trout, Oncorhynchus mykiss (Walbaum). J Fish Dis 23:423-427

> Thompson FL, Iida T, Swings J (2004) Biodiversity of vibrios. Microbiol Mol Biol Rev 68:403-431

- Thomson R, Macpherson HL, Riaza A, Birkbeck TH (2005) Vibrio splendidus biotype 1 as a cause of mortalities in hatchery-reared larval turbot, Scophthalmus maximus (L.). J Appl Microbiol 99:243-250

> Toranzo AE, Barja JL (1990) A review of the taxonomy and seroepizootiology of Vibrio anguillarum, with special reference to aquaculture in the northwest of Spain. Dis Aquat Org 9:73-82

Toranzo AE, Magarinos B, Romalde JL (2005) A review of the main bacterial fish diseases in mariculture systems. Aquaculture 246:37-61

Verner-Jeffreys DW, Shields RJ, Birkbeck TH (2003) Bacterial influences on Atlantic halibut Hippoglossus hippoglossus yolk-sac larval survival and start-feed response. Dis Aquat Org 56:105-113

Vik-Mo FT, Bergh O, Samuelsen OB (2005) Efficacy of orally administered flumequine in the treatment of vibriosis caused by Listonella anguillarum in Atlantic cod Gadus morhua. Dis Aquat Org 67:87-92

Wiik R, Hoff KA, Andersen K, Daae FL (1989) Relationships between plasmids and phenotypes of presumptive strains of Vibrio anguillarum isolated from different fish species. Appl Environ Microbiol 55:826-831

Wiik R, Stackebrandt E, Valle O, Daae FL, Rødseth OM, Andersen K (1995) Classification of fish pathogenic vibrios based on comparative $16 \mathrm{~S}$ ribosomal-RNA analysis. Int J Syst Bacteriol 45:421-428

Wolf JC, Smith SA (1999) Comparative severity of experimentally induced mycobacteriosis in striped bass Morone saxatilis and hybrid tilapia Oreochromis spp. Dis Aquat Org 38:191-200

Editorial responsibility: Donald Evans, Athens, Georgia, USA
Submitted: December 17, 2008; Accepted: November 4, 2009 Proofs received from author(s): February 10, 2010 